Not only are they not getting it, but they can see no means by which, within the $\mathrm{SRC}$ as it stands, they can right the balance if it tips too much in the universities' direction.

$$
\text { Yours faithfully, }
$$

JOHN LYONS

Deputy General Secretary.

The Institution of Professional Civil

Servants,

Northumberland Street,

London WC2

\section{Orbital Planes of Planets}

SIR,-Recently (April 26) we attended a lecture at the University of the South, Sewanee, Tennessee, by Dr Peter Van de Kamp of Sproul Observatory, Swathmore, Pennsylvania. He spoke on "The Search for Extra-Solar Planets", his work for 35 years, which indicates that Barnard's star has two planetary companions bearing a similarity to Jupiter and Saturn.

This lecture restimulated an idea held by one of us (Wells) for several years. We know the ecliptic plane is practically at right angles to the plane of the galaxy, but we don't know if this is only by chance or of deep significance. After the lecture Dr Van de Kamp was asked if enough was known about the orbits of stars with companions to determine orbital planet orientation. He said he had not considered it but some work might well be devoted to the question. He commented on the planes of binaries as being apparently random.

During the 70 mile drive home, we discussed this further. It was decided that, since Dr Van de Kamp had not investigated this relationship, it may not ever have been properly considered.

It seems that one of the most fundamental bits of information that could come of extra-solar planet searches would be a determination of the distribution of orbital planes. If other solar systems besides ours should be found with the orbital planes also at right angles it would be suggestive, with probable implications for galactic evolution, as indeed would any significant deviation from random orientation of orbital planes.

Should a preferred orientation be established, it could have a great bearing on theories of galactic dynamics. It would seem that our solar system may have been formed approximately $90^{\circ}$ from the present galactic location initially, since difficulties are foreseen in trying to reconcile the ecliptic angle with fluid mechanics or condensation theories.

If we should be able to determine the plane of other ecliptics around other stars, it would greatly simplify the search for extra-solar planets by determining the directions from the stars to expect planets; a great advantage in radio astronomy or other scanning methods. For instance, Project Ozma was apparently limited in scan directions.

It was felt that this letter might bring comments from others on this question and help keep it before the attention of astronomers who might be able further to evaluate and pursue the phenomena.

Yours faithfully,

ERNEST H. WELLS

Daniel Payne Hale

National Aeronautics and

Space Administration,

George C. Marshall Space

Flight Center,

Huntsville, Alabama 35812

\title{
Obituary
}

\section{Lord Boyd Orr}

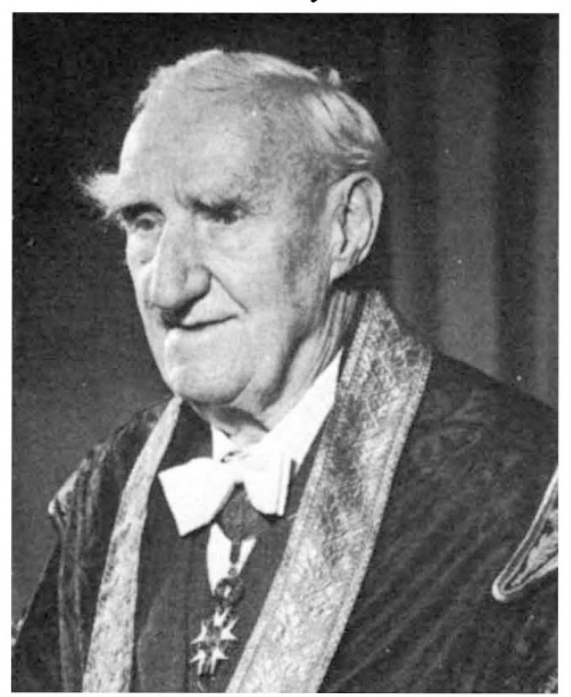

LORD BOYD ORR of Brechin Mearns, Nobel Peace Laureate, Chancellor of the University of Glasgow, first directorgeneral of the United Nations Food and Agricultural Organization, first director of the Rowett Research Institute and founder of the World Food Council, died on June 25 at the age of ninety.

John Boyd Orr was a graduate in arts, science and medicine of the University of Glasgow, where he also obtained his MD and DSc. His first external appointment was to a new research post in Aberdeen linked to the College of Agriculture and the university. This subsequently grew into the Rowett Research Institute. However, before he could get established the First World War began. Until 1917, he served with the RAMC, winning the DSO and MC with bar. Later he undertook an investigation of the physical requirements of servicemen for the navy.

Some of his first experience in nutritional investigation was gained in collaboration with the late Professor E. P. Cathcart at Glasgow. Here he worked chiefly on water and protein metabolism and on energy expenditure during work. There he was influenced by research on the diet of the working classes. On moving to Aberdeen, he took the advice of Cathcart and studied the mineral metabolism and needs of farm livestock, developing both topics with characteristic energy and insight. Some of his most impressive work was on mineral deficiencies and soil exhaustion in relation to pasture production both at home and abroad. This led him to establish a clinical unit to investigate the effects of husbandry techniques on the human populations of Masai and Kikuyu. It also established his interest in nutrition and disease and their interrelations.

$\mathrm{He}$ was responsible for great improvements in the production of meat, wool and milk, and helped to bring prosperity to the livestock industry. $\mathrm{He}$ gave the farmer more precise knowledge in the selection of food mixtures as a substitute for growing pastures, particularly in the wintering of his stock. He also gave some definition to the biochemical and immunological changes which precede and accompany the general symptoms of disordered metabolism caused by nutritional deficiency or imbalance. After starting work at the institute in a cellar of Marischal College, Orr received the financial backing of such men as Dr John Quiller Rowett (after whom the institute was named) and was able to establish at the institute the Imperial Bureau of Animal Nutrition.

Orr's professional concern was with animals of agricultural importance, but he found that whereas he had no difficulty in persuading farmers of the value to their stock and pockets of the application of sound nutritional principles, he could not convince anyone that the same was true of children. At that period the nutrition of man himself was an art rather than science, empiricism rather than experimentation, general impressions rather than controlled observation. But now, the newer knowledge of nutrition was growing, requirements could approximately be defined, and dietary surveys could expose the gap between requirement and that consumed. A large scale demonstration of the nutritious value of milk for school children partly done to promote the increased consumption 